ARTIKEL PENELITIAN

\title{
Karakteristik Nevus Pigmentosus berdasar atas Gambaran Histopatologi di Rumah Sakit Al-Islam Bandung
}

\author{
Ennok Nisa Islamiati, ${ }^{1}$ Siska Nia Irasanti, ${ }^{2}$ Mia Kusmiati, ${ }^{3}$ \\ Deis Hikmawati, ${ }^{4}$ Ismet M. Nur ${ }^{5}$ \\ ${ }^{1}$ Program Studi Pendidikan Dokter, Fakultas Kedokteran, Universitas Islam Bandung, \\ ${ }^{2}$ Bagian Ilmu Kesehatan Masyarakat, Universitas Islam Bandung \\ ${ }^{3}$ Dosen Fakultas Kedokteran, Universitas Islam Bandung \\ ${ }^{4}$ Patologi Anatomi, Universitas Islam Bandung, \\ ${ }_{5}^{5}$ Bagian Kulit dan Kelamin, Universitas Islam Bandung,
}

\begin{abstract}
Abstrak
Nevus pigmentosus (NP) merupakan lesi melanositik jinak yang paling umum, puncaknya pada usia 25 sampai 26 tahun. Faktor yang memengaruhinya di antaranya penuaan, pubertas, kehamilan, penggunaan kortikosteroid sistemik, faktor genetik, lingkungan, usia, dan jenis kelamin. Tujuan penelitian ini mengetahui karakteristik pasien NP berdasar atas gambaran histopatologi di Rumah Sakit Al-Islam Bandung. Penelitian ini menggunakan metode deskriptif cross-sectional menggunakan metode pengambilan sampel berupa total sampling. Data yang digunakan berupa data sekunder dari rekam medis periode 2012-2017 dan didapatkan data berjumlah 48 rekam medis. Pengolahan data dilakukan menggunakan program Microsoft Exel tahun 2011. Hasil penelitian menunjukkan frekuensi tertinggi NP terdapat pada usia 25-45 tahun sebanyak 23 kasus (48\%), NP lebih sering terjadi pada perempuan dibanding dengan laki-laki, nevus intradermal dengan jumlah 38 kasus (79\%), dan regio kepala dengan frekuensi 39 kasus (81\%). Perkembangan NP pada usia dewasa dapat disebabkan oleh beberapa kemungkinan di antaranya paparan sinar matahari, sering melakukan aktivitas di luar lingkungan, dan kurang penggunaan sunblock. Efek paparan sinar matahari secara langsung dapat menyebabkan proses melanogensis melalui aktivasi tirosinase akibat teraktivasinya protein kinase C. Simpulan penelitian ini menunjukkan frekuensi tertinggi NP terdapat pada usia 25-45 tahun dengan perbandingan perempuan lebih banyak dibanding laki-laki, serta gambaran histopatologi yang terbanyak adalah nevus intradermal yang berlokasi di regio kepala.
\end{abstract}

Kata kunci: Gambaran histopatologi, nevus pigmentosus

\section{The Characteristic of Nevus Pigmentosus based on Histopatological Features in Al-Islam Hospital Bandung}

\begin{abstract}
Nevus pigmentosus (NP) is the most common benign melanocytic lesion and peak at 25 to 26 years of age. The factors that influence NP is included aging, puberty, pregnancy, the used of systemic corticosteroid, genetic factors, environment, age, and gender. The purpose of this study was to describe the characteristics of NP patients based on histopathological features at Al-Islam Hospital Bandung. This study used a cross-sectional descriptive method using a total sampling method to collect the samples. The data used in this study is a secondary data from medical records 2012-2017 and obtained 48 medical records. Data processed by using the Microsoft Excel program 2011. The results showed that the highest frequency of NP occurred at the age of 25-45 years as many as 23 cases (48\%), NP is more common in women rather than men, nevus intradermal with 38 cases $(79 \%)$, and the head region with a frequency of 39 cases (81\%). The progression of NP in adult can be caused by several possibilities including sun exposure, frequent activities outside the environment and lack use of sunblock. The effects of direct sunlight exposure can cause the melanogenesis process through activation of tyrosinase due to activation of protein kinase C. The conclusions in this study showed that the highest frequency of NP is found at the age of 25-45 years old with a ratio of women is more than men, and the highest number of the histopathological features is intradermal nevus located in the head region.
\end{abstract}

Keywords: Histopathological features, nevus pigmentosus

Korespondensi: Ennok Nisa Islamiati. Prodi Pendidikan Sarjana Kedokteran Fakultas Kedokteran, Universitas Islam Bandung Jl. Hariangbanga no. 1, 40116, Kota Bandung, Provinsi Jawa Barat. HP : 082240935655, E-mail : nissaislamiatio1@gmail.com 


\section{Pendahuluan}

Nevus pigmentosus (NP) merupakan lesi melanositik jinak yang paling umum didapatkan pada semua usia. Walaupun NP bersifat jinak, namun NP dapat berkembang menjadi keganasan jika terdapat jumlah nevus yang lebih dari 100 nevus dapat memiliki risiko 8-10 kali dibanding dengan jumlah nevus yang lebih dari 50. Jumlah nevus akan meningkat dari lahir sampai awal masa dewasa dan akan memuncak sekitar usia 25 sampai 26 tahun, selanjutnya akan mengalami penyusutan secara bertahap dan menghilang seiring dengan berjalannya waktu dan telah dilaporkan pada usia 80 tahun nevus akan menghilang. ${ }^{1-4}$

Terdapat perbedaan berdasar atas tempat terjadi NP, yaitu di bagian batang tubuh, ekstremitas, kepala, leher, abdomen, dan bokong. Lokasi NP yang berada di daerah batang tubuh ditemukan pada orang berkulit putih dan laki-laki, sedangkan untuk yang berlokasi di daerah ekstremitas dapat ditemukan pada orang yang mempunyai kulit gelap dan perempuan. Untuk jenis nevus junctional didapatkan lebih sering di daerah yang tidak terpapar sinar matahari, sedangkan nevus intradermal dan compound ditemukan paling sering di daerah yang terpapar sinar matahari. ${ }^{1,5,6}$

Penelitian di Rumah Sakit Dr. Mohammad Hoesin Palembang menunjukkan bahwa kebanyakan nevus terjadi pada usia 30 sampai 39 tahun, perempuan lebih sering daripada laki-laki dengan rasio 2:1. Berdasar atas gambaran histopatologi, NP yang paling sering didapatkan gambaran nevus intradermal. Lokasi yang paling sering didapatkan adalah daerah kepala dan leher, sedangkan penelitian di Pulau Jawa di Poliklinik kulit subbagian bedah RSUD Dr. Moewardi Surakarta bahwa NP termasuk frekuensi kedua tersering. ${ }^{1,7}$

Berdasar atas latar belakang yang telah diuraikan maka tujuan penelitian adalah mengetahui gambaran karakteristik NP berdasar atas usia, jenis kelamin, lokasi, dan histopatologi NP di Rumah Sakit Al-Islam Bandung.

\section{Metode}

Penelitian mempergunakan metode deskriptif crosssectional dengan data sekunder berasal dari rekam medis seluruh pasien NP pada periode Januari 2012Desember 2017 dengan metode total sampling. Data yang dikumpulkan berupa usia, jenis kelamin, lokasi, dan gambaran histopatologi NP di Rumah Sakit AlIslam Bandung. Terdapat 48 kasus yang memenuhi kriteria inklusi, yaitu seluruh pasien NP yang telah dilakukan pemeriksaan histopatologi di Rumah Sakit Al-Islam Bandung periode Januari 2012-Desember 2017, sedangkan kriteria eksklusi pasien NP dengan data rekam medis yang tidak lengkap. Penelitian ini sudah mendapat persetujuan etik oleh Komite Etik Penelitian Kesehatan Fakultas Kedokteran Universitas Islam Bandung Nomor: 193/Komite Etik.FK/III/2018.

\section{Hasil}

Setelah pengumpulan dan pengolahan data pasien NP di Rumah Sakit Al-Islam Bandung diperoleh 48 kasus.
Tabel 1 Distribusi Nevus Pigmentosus berdasar atas Usia

\begin{tabular}{ccc}
\hline $\begin{array}{c}\text { Usia } \\
\text { (Tahun) }\end{array}$ & $\begin{array}{c}\text { Jumlah } \\
(\mathbf{n = 4 8 )}\end{array}$ & $\begin{array}{c}\text { Persentase } \\
(\mathbf{\%})\end{array}$ \\
\hline $0-5$ & 0 & 0 \\
$5-11$ & 2 & 4 \\
$12-25$ & 16 & 33 \\
$25-45$ & 23 & 48 \\
$45-65$ & 6 & 13 \\
$>65$ & 1 & 2 \\
\hline
\end{tabular}

Frekuensi tertinggi NP pada rentang usia 25-45 tahun sebanyak 23 kasus (48\%) dan frekuensi terendah pada rentang usia $>65$ tahun sebanyak 1 kasus (2\%) (Tabel 1).

Tabel 2 Distribusi Nevus Pigmentosus berdasar atas Jenis Kelamin

\begin{tabular}{lcc}
\hline $\begin{array}{c}\text { Jenis } \\
\text { Kelamin }\end{array}$ & $\begin{array}{c}\text { Jumlah } \\
(\mathbf{n = 4 8 )}\end{array}$ & $\begin{array}{c}\text { Persentase } \\
(\%)\end{array}$ \\
\hline Perempuan & 29 & 60 \\
Laki-laki & 19 & 40 \\
\hline
\end{tabular}

NP pada perempuan lebih banyak daripada lakilaki 60\% vs 40\% (Tabel 2).

Tabel 3 Distribusi Nevus Pigmentosus berdasar atas Gambaran Histopatologi

\begin{tabular}{|c|c|c|}
\hline $\begin{array}{l}\text { Gambaran } \\
\text { Histopatologi }\end{array}$ & $\underset{(n=48)}{\text { Jumlah }}$ & $\begin{array}{c}\text { Persentase } \\
\text { (\%) }\end{array}$ \\
\hline Junctional nevus & 6 & 13 \\
\hline Compound nevus & 4 & 8 \\
\hline Intradermal nevus & 38 & 79 \\
\hline
\end{tabular}

Gambaran histopatologi nevus intradermal 79\%, diikuti nevus junctional $13 \%$ dan nevus compound sebanyak 8\% (Tabel 3).

\section{Tabel 4 Distribusi Nevus Pigmentosus} berdasar atas Lokasi

\begin{tabular}{lcc}
\hline \multicolumn{1}{c}{ Lokasi } & $\begin{array}{c}\text { Jumlah } \\
(\mathbf{n = 4 8 )}\end{array}$ & $\begin{array}{c}\text { Persentase } \\
(\mathbf{\%})\end{array}$ \\
\hline Kepala & 39 & 81 \\
Leher & 3 & 6 \\
Ektremitas atas & 2 & 4 \\
Ekstremitas bawah & 0 & 0 \\
Toraks & 4 & 9 \\
Abdomen & 0 & 0 \\
\hline
\end{tabular}

Lokasi terjadi NP yang paling banyak adalah di regio kepala $81 \%$, regio toraks $9 \%$, regio leher $6 \%$, regio ekstremitas atas 4\%, sedangkan pada regio ekstremitas bawah dan abdomen tidak ditemukan. 


\section{Pembahasan}

Penelitian NP oleh Tsaniyah dkk.7 di Palembang dan Sugiura dan Sugiura ${ }^{6}$ di Jepang menunjukkan hal yang sama. Kesamaan hasil penelitian ini dapat disebabkan oleh perkembangan NP terjadi mulai usia anak-anak sampai dewasa muda, yaitu usia 20-50 tahun.3,4,6

Perkembangan NP pada usia yang dewasa dapat disebabkan oleh kemungkinan sering aktivitas di luar ruangan dan sering terpapar oleh sinar matahari tanpa mempergunakan sunblock dapat meningkatkan risiko perkembangan NP. Individu yang sering kali terpapar sinar matahari 5-9 kali memiliki risiko 2,2 kali lebih besar untuk perkembangan NP yang semakin membesar dibanding dengan individu yang memiliki kebiasaan terpapar sinar matahari o sampai 4 kali. Efek paparan sinar matahari yang secara langsung terhadap perkembangan NP mampu memengaruhi pelepasan diasilgliserol yang merupakan second messeger dari sinyal lipid pada proses melanogenesis itu. Pelepasan diasilgliserol mampu mengaktifkan protein kinase $C$, lalu dapat mengaktifkan tirosinase yang merupakan enzim yang berperan untuk mengubah tirosin menjadi 3,4-dehidroksifenilalanin (DOPA).,2,8-10

Faktor pencetus lain untuk perkembangan NP adalah mempergunakan kortikosteroid sistemik. Efek penggunaan kortikosteroid antara lain dapat menekan hypothalamic-pituitary-adrenal axis (HPA) apabila digunakan dengan dosis yang lebih tinggi, penggunaan dalam jangka waktu yang lama, dan digunakan lebih sering. Apabila menekan HPA maka kelenjar pituitari mampu menyintesis prekursor proopiomelanocortin (POMC), yaitu melanocyte stimulating hormone atau MSH dan adrenocorticotropic hormone atau ACTH yang merupakan stimulator yang poten terhadap melanogenesis. Melanocyte stimulating hormone dan ACTH merupakan proopiomelanocortin yang akan mengaktifkan melanocortin 1 receptor ( $\mathrm{MC1}$ ) yang akan berikatan dengan reseptor ligan, kemudian akan mengaktifkan protein $\mathrm{G}$ yang meningkatkan protein malanogenik termasuk tyrosinase. ${ }^{9}$

Hasil ini sama dengan penelitian yang dilakukan oleh Tsaniyah dkk. ${ }^{7}$ yang menyatakan bahwa NP lebih sering pada perempuan dengan rasio perempuan:lakilaki adalah 2:1.

Keadaan ini disebabkan oleh respons hormon seks tertentu. Nevus pigmentosus pada keadaan hamil akan terlihat makin gelap dan membesar disebabkan oleh peningkatan hormon estrogen dan progesteron pada saat kehamilan sehingga efek hormon tersebut mampu menginduksi melanogenesis dengan meningkatkan berbagai enzim melanogenik tirosinase dan protein tirosinase 1 (TRP-1) dan protein kinase 2 (TRP-2).

Proses pembentukan melanin dimulai dari aktivitas tirosinase yang akan mengubah tirosin menjadi DOPA, selanjutnya akan diubah dan mampu berpolimerasi membentuk melanin yang akhirnya melanin tersebut akan terakumulasi di dalam vesikel dan membentuk granul matang yang disebut melanosom. Di dalam melanosom perkembangan melanin dipengaruhi oleh ketiga enzim di atas, yaitu tirosinase, TRP-1, dan TRP2. Selanjutnya melanin yang terbentuk akan dikirim ke keratinosit melalui dendritik melanosit. ${ }^{10,13}$

Hasil penelitian berbeda dengan penelitian yang dilakukan di Finlandia oleh Sinikumpu dkk. ${ }^{2}$ bahwa jumlah NP sering ditemukan pada laki-laki dibanding dengan perempuan. Perbedaan tersebut disebabkan oleh kebanyakan populasi tersebut sering melakukan aktivitas di luar lingkungan yang terus menerus dan faktor perilaku.

Nevus intradermal merupakan jenis NP yang paling banyak didapatkan. Penelitian Sugiura dan Sugiura ${ }^{6}$ serta Tsaniyah dkk. ${ }^{7}$ pada populasi di Jepang juga mendapatkan hasil yang sama. ${ }^{6,7}$ Menurut teori Sugiura dan Sugiura ${ }^{6}$ nevus intradermal akan meningkat pada usia 20 tahunan sehingga nevus intradermal ini sering terlihat pada rentang usia 20-50 tahun, sedangkan nevus junctional dan compund puncak ditemukannya lebih rendah dibanding dengan nevus intradermal. ${ }^{6}$

Perkembangan NP diawali dengan nevus junctional yang ditandai terdapat sel yang berbentuk bulat sampai oval yang tumbuh di bagian dermoepidermal junction, kemudian nevus junctional ini akan tumbuh menuju ke bagian dermis yang disebut dengan nevus compound. Disebut nevus intradermal apabila sel yang tumbuh di bagian epidermis telah hilang. ${ }^{14}$

Perkembangan NP tersebut pada usia dewasa muda biasanya dikaitkan dengan sering terpapar oleh sinar matahari. Paparan sinar matahari merupakan salah satu faktor migrasi sel melanosit sehingga paparan sinar matahari ini dapat menyebabkan perkembangan nevus junctional di daerah terpapar sinar matahari, lalu akan bermigrasi ke bagian dari dermis. Oleh karena itu, nevus intradermal dan compound sering ditemukan di daerah yang terpapar sinar matahari daripada daerah yang tidak terpapar sinar matahari, sedangkan jenis nevus junctional sering ditemukan di daerah yang tidak terpapar sinar matahari., ${ }^{2,15}$

Penelitian oleh Tsaniyah dkk. ${ }^{7}$ menunjukkan lokasi tersering ditemukan NP adalah regio kepala dan leher. Beberapa faktor yang memengaruhi perkembangan nevus masih menjadi perdebatan, tetapi perkembangan nevus dipengaruhi oleh faktor genetik dan juga paparan sinar matahari sehingga perkembangan NP sering ditemukan di daerah yang sering terpapar sinar matahari seperti wajah, leher, lengan, dan bagian atas dada. Daerah wajah merupakan daerah yang sering terpapar sinar matahari sehingga jumlah NP yang ditemukan di daerah wajah lebih banyak. ${ }^{4,6}$

\section{Simpulan}

Berdasar atas penelitian ini dapat disimpulkan bahwa frekuensi tertinggi NP pada usia 25-45 tahun, lebih banyak pada perempuan, serta gambaran histopatologi adalah nevus intradermal di regio kepala.

\section{Ucapan Terima Kasih}

Terima kasih kepada responden seluruh pasien NP di Rumah Sakit Al-Islam Bandung.

\section{Daftar Pustaka}

1. Kariosentono H. Tinjauan pustaka: neoplasma jinak dan hiperplasia melanosit. MDVI. 2013;40(3):145-52. 
2. Sinikumpu SP, Huilaja L, Jokelainen J, Auvinen $\mathrm{J}$, Timonen M, Tasanen K. Association of multiple melanocytic naevi with education, sex and skin type. A Northern Finland Birth Cohort 1966 Study with 46 years follow-up. Acta Derm Venereol. 2017;97(2):219-24.

3. Rammel K. Classification of melanocytic nevi. Medical University of Graz, 2017 [diunduh 01 Februari 2018]. Tersedia dari: https://online. medunigraz.at/mug_online/wbabs.get Docum ent?pThesis $\mathrm{Nr}=53571 \&$ pAutorNr $=79751 \&$ pOrg $\mathrm{NR}=1$.

4. Black S, MacDonald-Mcmillan B, Mallett X, Rynn C, Jackson G. The incidence and position of melanocytic nevi for the purposes of forensic image comparison. Int J Legal Med. 2014;128(3):535-43.

5. Pagliarello C, Stanganelli I, Zambito-Spadaro F, Feliciani C, Nuzzo S. Sex differences in axial and limb distribution of melanocytic naevi. Acta Derm Venereol. 2017;97(2):266-7.

6. Sugiura K, Sugiura M. Pigmented nevus. J Clin Exp Dermatol Res. 2015;6(1):1-5.

7. Tsaniyah RAD, Aspitriani, Fatmawati. Prevalensi dan gambaran histopatologi nevus pigmentosus di bagian patologi anatomi Rumah Sakit Dr. Mohammad Hoesin Palembang periode 1 Januari 2009-31 Desember 2013. MKS. 2015;47(2):110-4.
8. İyidal AY, Gül Ü, Kılıç A. Number and size of acquired melanocytic nevi and affecting risk factors in cases admitted to the dermatology clinic. Postepy Dermatol Alergol. 2016;33(5):375-80.

9. Goldsmith LA, Katz SI, Gilchrest BA, Paller AS, Leffell DJ, Wolff K. Fitzpatrick dermatology in general medicine. Edisi ke-8. New York: McGrawHill; 2012.

10. Suryaningsih BE, Soebono H. Tinjauan pustaka: biologi melanosit. MDVI. 2016;43(2):78-82.

11. McCalmont T. Melanocytic nevi. 2016 [diunduh 23 Desember 2017]. Tersedia dari: https:// emedicine.medscape.com/article/1058445-over view.

12. Sumit K, Ajay K, Varna SP. Pregnancy and skin. J Obstet Gynecol India. 2012;62(3):268-75.

13. Mescher AL. Junqueira's basic histology text \& atlas. Edisi ke-14. New York: McGraw-Hill Education; 2016.

14. Kumar V, Abbas A, Aster J. Robbins basic pathology. Edisi ke-9. Philadelphia: Elsevier; 2013.

15. Oliveria SA, Scope A, Satagopan JM, Geller AC, Dusza SW, Weinstock MA, dkk. Factors associated with nevus volatility in early adolescence. J Invest Dermatol. 2014;134(9):2469-71. 